\title{
Ketyl radical formation of excited 1, 8-naphthalimides in protic polar solvent
}

\author{
Dae Won Cho ${ }^{\dagger}, *$, Dae Won Cho ${ }^{\ddagger}$, Hea Jung Park ${ }^{\S}$, Ung Chan Yoon ${ }^{\S}$, \\ Myoung Hee Lee ${ }^{\dagger}$, and Chan $\mathrm{Im}^{\dagger},{ }^{*}$,
}

${ }^{\dagger}$ Konkuk University-Fraunhofer ISE Next Generation Solar Cell Research Center, Konkuk University, Seoul 143701, Korea.

${ }^{\ddagger}$ Department of Chemistry, Yeungnam University, Gyeongsan 712749, Korea. ${ }^{\S}$ Department of Chemistry, Pusan National University, Pusan 609-734, Korea. "Department of Chemistry, Konkuk University, Seoul 143-701, Korea.

\begin{abstract}
Photoinduced electron-transfer process of 1,8-naphthalimide-linker-trimethylsilane (NI-O3-TMS, O3 = 3,6,9-trioxaundecyl) and $\mathrm{NI}-\mathrm{O} 3$ has been investigated using the transient absorption measurements in $\mathrm{CH}_{3} \mathrm{CN}$ and $\mathrm{CH}_{3} \mathrm{CN} / \mathrm{H}_{2} \mathrm{O}$. The excitation of $\mathrm{NI}-\mathrm{O} 3-\mathrm{TMS}$ in $\mathrm{CH}_{3} \mathrm{CN}$ produced the $\mathrm{NI}$ radical anion $\left(\mathrm{Nl}^{\circ}\right)$ with a transient absorption band around $413 \mathrm{~nm}$, via the intermolecular electron-transfer between $\mathrm{NI}$ moieties in the excited singlet state. In contrast, in a protic polar solvent mixture of $\mathrm{CH}_{3} \mathrm{CN} / \mathrm{H}_{2} \mathrm{O}$, a proton abstraction process occurred from $\mathrm{NI}^{*-}$ to generate the $\mathrm{NI}$ ketyl radical $\left(\mathrm{NIH}^{*}\right)$, which showed a transient absorption band around 405 $\mathrm{nm}$. The decay time constants of $\mathrm{NIH}^{*}$ were quite long compared to those of $\mathrm{Nl}^{-}$in $\mathrm{CH}_{3} \mathrm{CN}$.
\end{abstract}

1,8-Naphthalimides (NI) have attracted considerable interest because of their photophysical properties and potential applications in various scientific fields, such as photobiology. ${ }^{1-4}$ In many studies, NIs as an electron acceptor have been used for the investigation of photoinduced electron transfer (PET) from DNA as an electron donor. The PET mechanisms in DNA or biomaterial systems are of intrinsic interest because the reactions take place in aqueous or partially aqueous environments. Therefore, we have been studying the role of protons in the PET mechanism for NI dyads and bis $\mathrm{NI}$ systems. ${ }^{5,6}$ In protic polar solvent, the NI radical anions ( $\mathrm{NI}^{*}$ ) generated from the PET process undergoproton abstraction to produce the ketyl radical species $\left(\mathrm{NIH}^{*}\right)$ of $\mathrm{NI}$ in $\mathrm{CH}_{3} \mathrm{CN} / \mathrm{H}_{2} \mathrm{O}$. On the other hand,the covalently linked NI dyads with electron donor sites are often used to mimic PET processes in natural systems. ${ }^{7,8}$ Several electron donors can be introduced into NI-dyads. Among these, an organosilane is a unique electron donor in photocyclization reactions. ${ }^{9}$

*To whom correspondence should be addressed. E-mail:dwcho@konkuk.ac.kr

Received April 3. 2012. Accepted June 27. 2012
In this study, we examine the dynamic properties for photoreduced intermediates of NIs in aprotic as well as protic polar solvents. For the study, it was prepared a NI molecule (NI-O3-TMS) that have a linker (O3, where O3 is 3,6,9-trioxaundecyl and TMS is trimethylsilane) (Chart 1). We also synthesized NI-O3 as a reference, which were not trimethylsilylated (Chart 1). Nanosecond transient absorption measurements were carried out by employing the technique of laser flash photolysis. ${ }^{10}$ Femtosecond time-resolved absorption spectra were collected by a pumpprobe transient absorption spectroscopy system. ${ }^{10}$

Chart 1
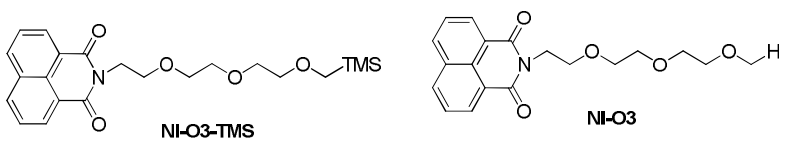

The transient absorption spectra of NI derivatives were obtained by nanosecond-laser flash photolysis measurement with 355-nm laser excitation. The transient absorption spectra of NI-O3-TMS $\left(3 \times 10^{-5}\right.$ M) measured in $\mathrm{CH}_{3} \mathrm{CN}$ and $\mathrm{CH}_{3} \mathrm{CN} / \mathrm{H}_{2} \mathrm{O}$ as shown in Figure 1.
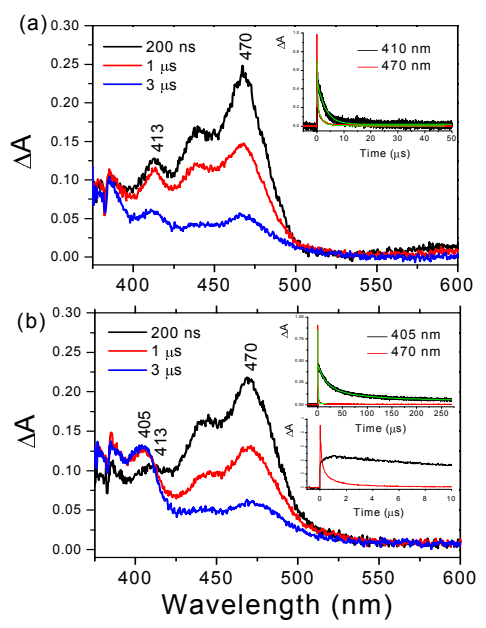

Figure 1. Transient absorption spectra of NI-O3-TMS in (a) $\mathrm{CH}_{3} \mathrm{CN}$, and (b) $\mathrm{CH}_{3} \mathrm{CN} / \mathrm{H}_{2} \mathrm{O}$. Inserts show the decay profiles monitored at 470 and $410 \mathrm{~nm}$ (or $405 \mathrm{~nm}$ ), respectively. Excitation wavelength was $355 \mathrm{~nm}$. 
The transient absorption spectra of NI-O3-TMS in $\mathrm{CH}_{3} \mathrm{CN}$ showed a characteristic band around $470 \mathrm{~nm}$, which might correspond to the $\mathrm{T}_{1}-\mathrm{T}_{\mathrm{n}}$ absorption of $\mathrm{NI}$ in the triplet excited state $\left({ }^{3} \mathrm{NI}^{*}\right){ }^{5,7,8}$ The transient band at $413 \mathrm{~nm}$ can be attributed to $\mathrm{NI}^{\circ}$, according to previous reports. ${ }^{7,8,11}$ The transient absorption of NI-O3-TMS decayed with first-order kinetics as illustrated in the inset of Figure 1a; the decay lifetime of ${ }^{3} \mathrm{NI}^{*}$-O3-TMS was estimated to be $0.14 \mu$ s at the $470-\mathrm{nm}$ wavelength. At the 410-nm wavelength, the decay lifetime of NI-O3TMS was $3.0 \mu \mathrm{s}$, which was attributed to the intermolecular charge recombination (CR) process between $\mathrm{NI}^{*}$ and the cation radical moiety $\left(\mathrm{NI}^{\cdot+}\right)$. There is no rise component corresponding to the decay of ${ }^{3} \mathrm{NI}^{*}$ at $470 \mathrm{~nm}$. These observations mean that the intermolecular PET process takes place from the excited singlet state in $\mathrm{CH}_{3} \mathrm{CN}$.

In $\mathrm{H}_{2} \mathrm{O} / \mathrm{CH}_{3} \mathrm{CN}(\mathrm{v} / \mathrm{v}=9: 1)$, the $\mathrm{T}_{1}-\mathrm{T}_{\mathrm{n}}$ absorption of $\mathrm{NI}$ -O3-TMS was observed at $470 \mathrm{~nm}$, with weak transient absorption bands at 413 and $405 \mathrm{~nm}$ (Figure 1b). In addition, the transient absorption bands showed different kinetic traces, as shown in the inset of Figure 2b. The $\mathrm{T}_{1}-\mathrm{T}_{\mathrm{n}}$ absorption at $470 \mathrm{~nm}$ decayed with a lifetime of $4.4 \mu \mathrm{s}$. On the other hand, the transient absorption at $405 \mathrm{~nm}$ showed an initial formation and then a very slow decay with a lifetime of $50 \mu$ s. The growth at 405 nm occurred concomitantly with the decay of the $T_{1}-T_{n}$ absorption at $470 \mathrm{~nm}$. The quenching mechanism of ${ }^{3} \mathrm{NI}^{*}$ by using another NI was previously suggested. ${ }^{5,6,12,13}$

Figure 2a shows the femtosecond time-resolved transient absorption spectra of NI-O3-TMS in $\mathrm{CH}_{3} \mathrm{CN}$. Upon excitation of $130 \mathrm{fs}$ pulse at $330 \mathrm{~nm}$, a transient absorption bands were observed around $465 \mathrm{~nm}$. This band can be assigned to $\mathrm{S}_{1}-\mathrm{S}_{\mathrm{n}}$ absorption band of $\mathrm{NI}^{14}$ On the other hand, a transient absorption band at 415 $\mathrm{nm}$ increased gradually according to time delay as shown in inset decay profiles of Figure 2a. It is noteworthy that the growth of $\mathrm{NI}^{-}$transient bands for NI -O3-TMS at $415 \mathrm{~nm}$ occurs concomitantly with the decay of the $\mathrm{S}_{1}-\mathrm{S}_{\mathrm{n}}$ absorption at $480 \mathrm{~nm}$ (inset in Figure 2a). This indicates that the $\mathrm{NI}^{*}$ species produced after formation of ${ }^{1} \mathrm{NI}^{*}$ which is precursor of $\mathrm{NI}^{*-}$ species having an absorption at $415 \mathrm{~nm}$.

Figure $2 \mathrm{~b}$ shows the femtosecond time-resolved transient absorption spectra of NI-O3-TMS in $\mathrm{CH}_{3} \mathrm{CN} / \mathrm{H}_{2} \mathrm{O}$. Overall spectral changes of NI-O3-TMS in $\mathrm{CH}_{3} \mathrm{CN} / \mathrm{H}_{2} \mathrm{O}$ are similar with those in $\mathrm{CH}_{3} \mathrm{CN}$ except only longer dynamics. Actually, the fluorescence lifetimes in the singlet excited state were measured to be 0.31 ns in $\mathrm{CH}_{3} \mathrm{CN}$, and 0.55 ns in $\mathrm{CH}_{3} \mathrm{CN} / \mathrm{H}_{2} \mathrm{O}$. Consequently, the fluorescence quantum yields of NI-O3-TMS increase in protic polar solvent: 0.024 in $\mathrm{CH}_{3} \mathrm{CN}$ and 0.054 in $\mathrm{CH}_{3} \mathrm{CN} / \mathrm{H}_{2} \mathrm{O}$. This result indicates that the protic polar solvent forms a hydrogen bonding with the excited molecule. ${ }^{15}$

The transient absorption band at $405 \mathrm{~nm}$ in protic polar solvent can be attributed to $\mathrm{NIH}^{\circ}$, according to previous works. $^{5,6,16}$ The ketyl radical species of naphthalimide or phthalimides have been suggested as intermediates in photocyclization reactions with a lack of direct evidence. ${ }^{9}$ The ketyl radical is electrically neutral and not a charged species, therefore, the regeneration process of NI derivatives is slow. Thus, the transient absorption band at $405 \mathrm{~nm}$ shows a longer decay time of a few tens of microseconds. The long lifetime of the ketyl radical is beneficial for the photocyclization reaction.
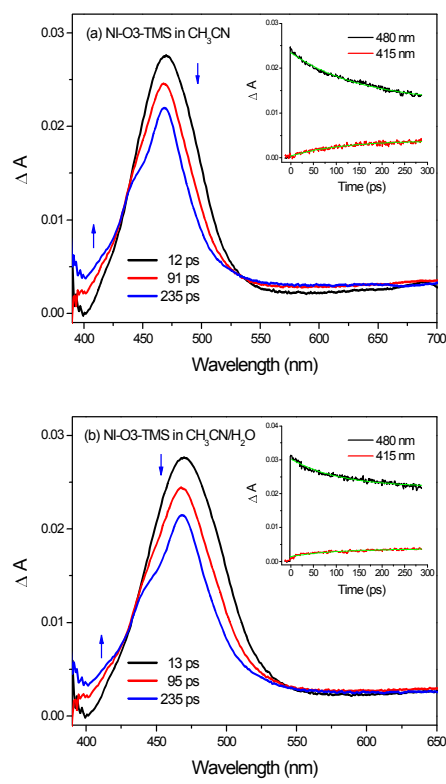

Figure 2. Femtosecond time-resolved transient absorption spectra of NI-O3-TMS in $\mathrm{CH}_{3} \mathrm{CN}$ (a) and $\mathrm{CH}_{3} \mathrm{CN} / \mathrm{H}_{2} \mathrm{O}$. Inset figures show the decay profiles monitored at 480 and $415 \mathrm{~nm}$, respectively. Excitation wavelength is 330 nm.

Table 1. Decay Time Constants of Triplet-state $\left(\tau_{\top}\right)$, Anion Radical $\left(\tau_{\mathrm{A}}\right)$ and Ketyl Radical $\left(\tau_{\mathrm{K}}\right)$ Species in $\mathrm{CH}_{3} \mathrm{CN}$ and $\mathrm{CH}_{3} \mathrm{CN} / \mathrm{H}_{2} \mathrm{O}$

\begin{tabular}{ccccc}
\hline & \multicolumn{2}{c}{ in $\mathrm{CH}_{3} \mathrm{CN}$} & \multicolumn{2}{c}{ in $\mathrm{CH}_{3} \mathrm{CN} / \mathrm{H}_{2} \mathrm{O}$} \\
\cline { 2 - 5 } & $\tau_{\mathrm{T}}(\mu \mathrm{s})$ & $\tau_{\mathrm{A}}(\mu \mathrm{s})$ & $\tau_{\mathrm{T}}(\mu \mathrm{s})$ & $\tau_{\mathrm{K}}(\mu \mathrm{s})$ \\
\hline NI-O3-TMS & 0.14 & 3.0 & 0.10 & 35 \\
\hline
\end{tabular}

However, the quantum efficiency of the intermolecular PET process of ${ }^{3} \mathrm{NI}^{*}-\mathrm{O} 3$ in both solvents is quite small, because the anion radical species of NI was not detected in the ns-transient absorption spectrum.

In conclusion, the intermolecular $\mathrm{PET}$ process was observed. In $\mathrm{CH}_{3} \mathrm{CN} / \mathrm{H}_{2} \mathrm{O}$, the PET process occurred in addition to the formation of $\mathrm{NIH}^{*}$, which exhibited a long lifetime. The intermolecular PET process for NI-O3-TMS may take place in both the excited singlet and triplet states. The results, observed by the transient absorption spectroscopic technique, showed that $\mathrm{NI}^{*}$ is converted to the NI ketyl radical $\left(\mathrm{NIH}^{*}\right)$ species in protic polar solvent as following mechanism. 


$$
\mathrm{NI} \stackrel{\text { hv }}{\rightarrow}{ }^{1} \mathrm{NI}^{*} \rightarrow{ }^{\mathrm{ISC}} \mathrm{NI}^{*}
$$

${ }^{1} \mathrm{NI}^{*}\left(\right.$ or $\left.{ }^{3} \mathrm{NI}^{*}\right)+\mathrm{NI} \rightarrow \stackrel{\text { PET }}{\rightarrow} \mathrm{NI}^{-\bullet}+\mathrm{NI}^{+\bullet} \stackrel{\mathrm{H}_{2} \mathrm{O}}{\rightarrow} \mathrm{NI}(\mathrm{H})^{\bullet}+\mathrm{NI}^{+\bullet}$

Received: Sept 01, 2012

Revised: Sept 07, 2012.

Published online: Sept 15, 2012

KEYWORDS: 1,8-naphthalimide, photoinduced electron transfer,

\section{ACKNOWLEDGEMENT}

This work was supported by the Seoul R\&BD Program (WR090671) and Solar Energy Industrial R\&D Exchange and Cooperation Project (2011) from Seoul Metropolitan Government.

\section{SUPPORTING INFORMATION}

Experimental procedures; experimental details. This material is available free of charge via the Internet at http://www.rcp.or.kr

\section{REFERENCES AND NOTES}

1. Saito, I.; Takayama, M.; Sugiyama, H.; Nakatani, K.; Tsuchida, A.; Yamamoto, M. J. Am. Chem. Soc. 1995, 117, 6406.

2. Rogers, J. E.; Kelly, L. A. J. Am. Chem. Soc. 1999, 121, 3854.

3. Kawai, K.; Osakada, Y.; Matsutani, E.; Majima, T. J. Phys. Chem. B 2010, 114, 10195.

4. Takada, T.; Takeda, Y.; Fujitsuka, M.; Majima, T. J. Am. Chem. Soc. 2009, 131, 6656.

5. Cho, D. W.; Fujitsuka, M.; Yoon, U. C.; Majima, T. Phys. Chem. Chem. Phys. 2008, 10, 4393.

6. Cho, D. W.; Fujitsuka, M.; Sugimoto, A.; Majima, T. J. Phys. Chem. A, 2008, 112, 7208.

7. Cho, D. W.; Fujitsuka, M.; Sugimoto, A.; Yoon, U. C.; Mariano, P. S.; Majima, T. J. Phys. Chem. B, 2006, 110, 11062.

8. Cho, D. W.; Fujitsuka, M.; Yoon, U. C.; Majima, T. J. Photochem. Photobiol. A: Chem. 2007, 190, 101.

9. Cho, D. W.; Yoon, U. C.; Mariano, P. S. Acc. Chem. Res. 2011, 44, 204.

10. Cho, D. W.; Fujitsuka, M.; Ryu, J. H.; Lee, M. H.; Kim, H. K.; Majima, T.; Im, C. Chem. Comm., 2012, in press

11. Jones II, G.; Kumar, S. J. Photochem. Photobiol. A: Chem. 2003, 160, 139.

12. Aveline, B. M.; Matsugo, S.; Redmond, R. W. J. Am. Chem. Soc. 1997, 119, 11785.

13. Li, H. -Q.; Jiang, Z. -Q.; Wang, X.; Pan, Y.; Wang, F.; Yu, S. -O. Res. Chem. Intermed., 2004, 30, 369.
14. Smanta, A.; Saroja, G. J. Photochem. Photobiol. A: Chem., 1994, 84, 19.

15. Wintgens, V.; Valet, P.; Kossanyi, J.; Biczロk, L.; Demeter, A.; B $\square$ rces, T. J. Chem. Soc., Faraday Trans. 1994, 90, 411.

16. Demeter, A.; Biczロk, L.; Bロrces, T.; Wintgens, V.; Valat, P.; Kossanyi, J. J. Phys. Chem. 1993, 97, 3217. 